\title{
Three-dimensional evaluation of extended-pour alginate impressions depending on storage conditions
}

\section{Trójwymiarowa ocena wycisków pobranych masami alginatowymi o wysokiej stabilności wymiarowej w zależności od warunków przechowywania}

\author{
Marcin Szerszeñ', Aleksandra Sochańska', Agnieszka Ochat ${ }^{2}$, \\ Kamila Wróbel-Bednarz ${ }^{1}$ \\ ${ }^{1}$ Katedra Protetyki Stomatologicznej, Warszawski Uniwersytet Medyczny \\ Department of Prosthetic Dentistry, Medical University of Warsaw \\ Head: prof. dr hab. n. med. Jolanta Kostrzewa-Janicka \\ ${ }^{2}$ Studenckie Koło Naukowe, Katedra Protetyki Stomatologicznej, Warszawski Uniwersytet Medyczny \\ Students' Research Group, Department of Prosthodontics
}

KEY WORDS:

storage conditions, alginate impression, threedimensional scanning

\section{Summary}

Background. For many years, alginates have remained the most frequently chosen impression materials in the initial stages of treatment due to their numerous advantages, such as ease of insertion and removal from the oral cavity, or low cost of the material. In recent years, alginate impression materials called "extended-pour" have appeared on the dental market, allowing clinicians to make plaster models even after a few days.

Aim. The aim of the study was to perform a three-dimensional evaluation of extendedpour alginate impressions depending on the environment and storage time.

Material and methods. A series of threedimensional images of forty impressions made of high dimensional stability alginate were tested. The scans were divided into groups depending on the conditions of storing the impressions. The three-dimensional images were superimposed using graphic software, and the deviations were calculated. Data in the form of 5600 deviation values were subjected to statistical analysis.

\section{HASŁA INDEKSOWE:}

warunki przechowywania, wyciski alginatowe, skanowanie trójwymiarowe

\section{Streszczenie}

Wprowadzenie. Masy alginatowe nieustannie pozostaja najczesściej wybieranymi materiatami wyciskowymi $w$ poczatkowych etapach leczenia ze względu na swoje zalety, takie jak: tatwość wprowadzenia $i$ usunięcia z jamy ustnej, niska cena materiatu czy akceptowalny dla pacjenta smak $i$ zapach. W ostatnich latach pojawity sie masy alginatowe o tzw. wysokiej stabilności wymiarowej, pozwalajace na wykonanie na ich podstawie modelu nawet po kilku dniach. Masy alginatowe, ze względu na znaczna zawartość wody, ulegaja samorzutnie zachodzacym procesom synerezy i imbibicji. Środowisko przechowywania wycisku alginatowego pozostaje tematem aktualnym, szczególnie w obliczu przedtużonego czasu do momentu wykonania na jego podstawie modelu gipsowego.

Cel pracy. Celem pracy była trójwymiarowa ocena wycisków z mas alginatowych o wysokiej stabilności wymiarowej w zależności od środowiska i czasu ich przechowywania.

Material $\boldsymbol{i}$ metody. Do badań wykorzystano serie trójwymiarowych obrazów, czterdziestu wy- 
Results. The lowest mean values of deviations in the 24 hours of the study were obtained for the group kept in a double-zipped bag at room temperature without the presence of an external source to increase humidity. The highest mean deviations were obtained at 144 hours of study for impressions stored in a double-zipped bag at the temperature of $5^{\circ} \mathrm{C}$ without the presence of an external source of humidity.

Conclusions. The storage time and environment affect the spatial dimensions of the high dimensional stability alginate impressions. The presence of an external source of humidity during the storage of the alginate impressions does not significantly improve the dimensional stability.

\section{Introduction}

Despite the dynamic development of digital methods of intraoral imagining, alginate impression materials remain the most frequently used materials in the process of initial mapping of the prosthetic field. Numerous advantages such as the ease of handling, satisfactory accuracy, low cost, acceptable taste and smell, and a relatively short setting time, result in the fact that alginate impression material is pleasant to use both for the patient and the doctor. Plaster models prepared from alginate impressions are used not only for diagnostic purposes but also for treatment planning, as well as for the working models to manufacture long-term prosthetic restorations, orthodontic appliances or mouthguards. ${ }^{1-7}$ From the chemical point of view, alginate impression materials are a cisków wykonanych z masy alginatowej o tzw. wysokiej stabilności wymiarowej. Skany podzielono na grupy w zależności od warunków przechowywania wycisków. Trójwymiarowe obrazy nakładano na siebie wykorzystujac oprogramowanie graficzne oraz obliczano odchylenia w 24 i 144 godzinie badania. Dane w postaci 5600 wartości odchyleń zostaty poddane analizie statystycznej.

Wyniki. Najmniejsze średnie wartości odchyleń w 24 godzinie badania uzyskano dla grupy przechowywanej $w$ torbie strunowej, $w$ temperaturze pokojowej bez obecności zewnętrznego źródta zwiększajacego wilgotność. Największe średnie odchylenia uzyskano w 144 godzinie badania dla wycisków przechowywanych $w$ torbie strunowej, $w$ temperaturze $5 \mathrm{C}$ bez obecności zewnętrznego źródła wilgotności.

Wnioski. Czas i środowisko przechowywania maja wptyw na zmianę wymiarów przestrzennych wycisków z mas alginatowych o tzw. wysokiej stabilności wymiarowej. Obecność zewnętrznego źródła zwiększajacego wilgotność podczas przechowywania wycisków alginatowych nie wpływa znaczaco na polepszenie stabilności wymiarowej.

\section{Wstęp}

Masy alginatowe, pomimo dynamicznie rozwijających się cyfrowych metod obrazowania tkanek jamy ustnej, pozostają najczęściej wykorzystywanym materiałem wyciskowym w celu wstępnego odwzorowania pola protetycznego. Liczne zalety w postaci łatwości w przygotowaniu materiału, zadowalającej precyzji, niskiej ceny, akceptowalnego smaku i zapachu czy stosunkowo krótkiego czasu wiązania powodują, iż jest to masa wyciskowa przyjemna w użyciu dla pacjenta i lekarza. Modele gipsowe wykonane na podstawie wycisków z mas alginatowych są wykorzystywane zarówno w celach diagnostycznych, planowania leczenia, jak i jako modele robocze do wykonania długoczasowych uzupełnień protetycznych czy aparatów ortodontycznych. ${ }^{1-6}$ 
mixture of several substances: salts (sodium, potassium, ammonium, triethanolamine) of alginic acid, diatomaceous earth, talc, calcium carbonate, zinc oxide, fluorides (potassium or titanium), potassium sulfate, and flavours. Alginic acid is a polysaccharide acquired from the process of cell wall extraction of brown algae belonging mainly to the Phaeophyceae family. The main inorganic compound component? of alginate filler is diatomaceous earth, representing the fossilized remains of algae (e.g. Bacillariophyceae class, presumably from the Cretaceous period). ${ }^{1-3}$ Alginate impression materials are classified as irreversible hydrocolloid materials. ${ }^{8}$ Gelification of material (transition from sol to gel) develops after the introduction of water into the alginate powder, which results in a chemical reaction of sodium alginate with calcium sulfate, according to the formula:

$$
2 \mathrm{Na}_{3} \mathrm{PO}_{4}+3 \mathrm{CaSO}_{4} \rightarrow \mathrm{Ca}_{3}\left(\mathrm{PO}_{4}\right)_{2}+3 \mathrm{Na}_{2} \mathrm{SO}_{4}
$$

the reaction which can be restrained by the insertion of calcium phosphate, functioning as a reaction inhibitor. ${ }^{2,9}$ Due to water-rich content in the bound alginate mass (about 85\%), it undergoes spontaneous imbibition and syneresis phenomena. Imbibition is the process of swelling due to the further attachment of water molecules to the hydrophilic colloid molecules. Syneresis is the reverse process - it represents the shrinkage of the material due to the loss of slight fluid volume. As a result of these phenomena, important for spatial dimensions, it is common knowledge among the clinicians that it is necessary to pour the impression as soon as possible. ${ }^{10-12}$ Over the years, the composition of alginate impression materials has been modified by adding new substances to eliminate disadvantages such as: poor tear strength, dimensional instability or biocompatibility issues connected with the dust generated during material handling. One
Pod kątem chemicznym masy alginatowe są mieszaniną kilku substancji, między innymi: soli (sodowej, potasowej, amonowej, trietanoloaminowej) kwasu alginowego, ziemi okrzemkowej, talku, węglanu wapnia, tlenku cynku, fluorków (potasu lub tytanu), siarczanu potasu oraz środków smakowych i zapachowych. Kwas alginowy jest polisacharydem otrzymywanym jest poprzez wyekstrahowanie ścian komórkowych brunatnic należących głównie do rodziny Phaeophyceae. Głównym nieorganicznym związkiem wypełniacza mas alginatowych jest natomiast ziemia okrzemkowa będąca skamieniałymi szczątkami glonów (np. klasy Bacillariophyceae prawdopodobnie z okresu kredy). ${ }^{1-3}$ Masy alginatowe zaliczane są do nieodwracalnych hydrokoloidowych materiałów wyciskowych. Żelifikacja materiału (przejście z fazy zolu w żel) następuje po wprowadzeniu do proszku alginatowego wody wyzwalającej reakcję chemiczną alginianu sodowego z siarczanem wapnia wg wzoru:

$2 \mathrm{Na}_{3} \mathrm{PO}_{4}+3 \mathrm{CaSO}_{4} \rightarrow \mathrm{Ca}_{3}\left(\mathrm{PO}_{4}\right)_{2}+3 \mathrm{Na}_{2} \mathrm{SO}_{4}$

reakcja ta może być opóźniona przez wprowadzenie fosforanu wapnia działającego jako inhibitor. ${ }^{2,7}$ Ze względu na dużą zawartość wody w związanej masie alginatowej (około $85 \%$ ) ulega ona samorzutnie zachodzącym zjawiskom imbibicji i synerezy. Imbibicja jest procesem pęcznienia na skutek przyłączania się coraz większej ilości cząsteczek wody do cząsteczek hydrofilnego koloidu. Synereza jest procesem odwrotnym - polega na kurczeniu się masy poprzez wydzielanie $\mathrm{z}$ niej małej objętości płynu. Ze względu na te istotne pod kątem wymiarów przestrzennych zjawiska, powszechna wśród klinicystów jest wiedza, iż gipsowe modele na podstawie wycisków alginatowych najlepiej jest odlewać jak najszybciej. ${ }^{8-10} \mathrm{Na}$ przestrzeni wielu lat dokonywano modyfikacji składu mas alginatowych dodając do nich nowe substancje mające wyeliminować 
of the effects obtained from a development in the alginate powder composition is the recent appearance on the dental market of alternative materials with the so-called -"high dimensional stability" (extended-pour alginates). 2,13,14

\section{The aim of the study}

The aim of the study was a three-dimensional evaluation of extended-pour alginate impressions depending on the environment and storage time.

\section{Materials and methods}

In this experimental study, forty identical alginate impressions were made using a specially constructed tool (NS-ASA), which ensured the standard position of the model in relation to the impression tray. Each impression was assigned a number from 1 to 40 . The tool was developed on the basis of the articulator (Articulator 5010, ASA Dental, Massarosa, Italia) by attaching to its upper part a standard toothed phantom model of the upper jaw (ANA-4, Frasaco, Tettnang, Germany). In the lower part, the occlusal table was attached, on top of which a silicone index was positioned to ensure the placement of an impression tray exclusively in one specific position. The impressions were taken with an alginate impression materialspecified by the manufacturer as one with high dimensional stability (extended-pour alginate) (Hydrogum 5, Zhermack, Badia Polesine, Italia) on the size 3 standard impression trays, designed for the dentate upper arch (Opti-Tray OK 3, Profimed, Katowice, Poland). To ensure the support of the incisal rod against the occlusal table on the NS-ASA, the impression tray handles were modified to form a wide notch. The alginate impression materialwas prepared by mixing the powder with distilled water in the ratio recommended by the manufacturer $(14 \mathrm{~g} /$ $30 \mathrm{ml}$ ), initially by manual mixing with a plastic takie mankamenty jak: niska wytrzymałość na rozdzieranie, niestabilność wymiarów czy problemy z biokompatybilnością pyłu powstającego podczas manipulacji materiałem. Jednym z efektów rozwoju w zakresie składu proszku alginatowego jest pojawienie się $\mathrm{w}$ ostatnich latach na rynku stomatologicznym obok konwencjonalnych mas alginatowych, alternatywnych, o tak zwanej - wysokiej stabilności wymiarowej (ang. extended-pour alginates). ${ }^{2,11,12}$

\section{Cel pracy}

Celem pracy była trójwymiarowa ocena wycisków z mas alginatowych o wysokiej stabilności wymiarowej w zależności od środowiska i czasu ich przechowywania.

\section{Material i metody}

Wykonano 40 identycznych wycisków alginatowych wykorzystując $w$ tym celu, specjalnie skonstruowane, narzędzie standaryzujące (NSASA) położenie modelu uzębienia względem łyżki wyciskowej. Każdemu wyciskowi przypisano liczbę od 1 do 40. Narzędzie zostało opracowane na podstawie artykulatora (Artykulator 5010, ASA Dental, Massarosa, Italia) poprzez zamontowanie w jego górnej części uzębionego standardowego modelu fantomowego (ANA-4, Frasaco, Tettnang, Germany), w dolnej części został zamontowany stolik okluzyjny, na którym wykonano silikonowy stelaż umożliwiający umieszczenie na nim łyżki wyciskowej tylko w jednym określonym położeniu. Wyciski były pobierane masą alginatową określoną przez producenta jako materiał o wysokiej stabilności wymiarowej (Hydrogum 5, Zhermack, Badia Polesine, Italia) na łyżkach standardowych wielkości 3, przeznaczonych do uzębionego łuku górnego (Opti-Tray OK 3, Profimed, Katowice, Polska). Aby umożliwić podparcie sztyftu siecznego o stolik sieczny w narzędziu NS-ASA, dokonano modyfikacji uchwytów 
spatula, then using an alginate mixing device (Alghamix II, Zhermack, Badia Polesine, Italia) for the recommended time ( $<30$ seconds). After applying the material to the impression tray, it was positioned on the silicone index of the NS-ASA instrument, and the phantom model attached to the upper part of NS-ASA was embedded in the alginate material until the incisal pin touched the NS-ASA occlusal table. These steps were repeated to obtain identical impressions.

After the alginate material had completely set, each impression was removed from the NS-ASA instrument, given an order number from 1 to 40, and then immediately scanned with an optical scanner (Trios, 3Shape, Copenhagen, Denmark). The established scanning protocol included mainly tooth impressions and $1 / 3$ of the anterior part of the palate. In order to minimize the possibility of the scanner's technical accuracy having an impact on the test results, the minimum (1950) and maximum (2000) number of three-dimensional image shots were assumed for each scanning procedure. The threedimensional images were then exported from native software (Dental Desktop, 3Shape, Copenhagen, Denmark) in the form of STL (Standard Tessellation Language) files. Scans prepared in such a manner determined a reference group for the comparisons of threedimensional images (initial scans). When the initial scans were performed, all impressions were placed in sealed double-zipped bags. The impressions were randomized using a website application (http://randomization. com), divided into sets of equal numbers and assigned to four groups (A, B, C, D). In the first group (A), alginate impressions were stored at room temperature $\left(23 \pm 1^{\circ} \mathrm{C}\right)$. The second group (B) comprised alginate impressions placed in cooling conditions $\left(5 \pm 1^{\circ} \mathrm{C}\right)$. In the third group (C), the wet paper towel was placed inside the double-zipped bags in such łyżek wyciskowych w postaci szerokiego nacięcia. Masa alginatowa była przygotowywana poprzez mieszanie proszku z wodą destylowaną $\mathrm{w}$ zalecanym przez producenta stosunku $(14 \mathrm{~g} / 30 \mathrm{ml})$, najpierw poprzez manualne mieszanie plastikową szpatułą, następnie wykorzystując urządzenie do mieszania mas alginatowych (Alghamix II, Zhermack, Badia Polesine, Italia) przez zalecany czas ( $<30$ sekund). Po nałożeniu masy na łyżkę wyciskową, była ona umieszczana na silikonowym stelażu narzędzia NS-ASA, po czym model ćwiczeniowy zamontowany w górnej części NS-ASA był zatapiany w masie alginatowej do momentu zetknięcia sztyftu siecznego ze stolikiem siecznym NS-ASA. Czynności te były powtarzane w celu otrzymania identycznych wycisków.

Po całkowitym związaniu masy alginatowej każdy wycisk był wyjmowany z narzędzia NSASA, nadawano mu numer porządkowy od 1 do 40, a następnie bezzwłocznie poddawano skanowaniu przy pomocy skanera optycznego (Trios, 3Shape, Copenhagen, Denmark). Założony protokół skanowania obejmował głównie impresje zębów oraz 1/3 przednią część podniebienia. W celu zminimalizowania możliwości wpływu dokładności technicznej skanera na wyniki badań założono minimalną (1950) i maksymalną (2000) liczbę ujęć trójwymiarowego obrazu dla każdej procedury skanowania. Trójwymiarowe obrazy były następnie eksportowane z natywnego oprogramowania (Dental Desktop, 3Shape, Copenhagen, Denmark) w postaci plików STL (ang. Standard Tessellation Language). Tak przygotowane skany stanowiły grupę odniesienia dla porównań trójwymiarowych obrazów (skany wstępne). Po wykonaniu skanów wstępnych wszystkie wyciski były umieszczane w szczelnie zamkniętych torebkach z podwójnym zapięciem strunowym. Wyciski zostały podzielone na, randomizowane przy pomocy aplikacji na stronie internetowej (http://randomization. com), równoliczne zbiory oraz przyporządkowane do 4 grup (A, B, C, D). W grupie pierwszej 
Ta b le 1. Allocation of alginate impressions into groups with a list of numbers and the characteristics of the storage environment

\begin{tabular}{|c|c|c|c|c|}
\hline Group & $\begin{array}{c}\text { Storage } \\
\text { temperature }\end{array}$ & $\begin{array}{c}\text { The presence of } \\
\text { a damp towel } \\
\text { in a zipper bag }\end{array}$ & $\begin{array}{c}\text { Number of } \\
\text { impressions } \\
\text { in the group }\end{array}$ & $\begin{array}{c}\text { Impression numbers assigned } \\
\text { to groups by randomization }\end{array}$ \\
\hline $\mathrm{A}$ & $23 \pm 1^{\circ} \mathrm{C}$ & absence & 10 & $19,21,11,2,7,38,28,26,22,18$ \\
\hline $\mathrm{B}$ & $5 \pm 1^{\circ} \mathrm{C}$ & absence & 10 & $35,6,13,25,17,31,14,27,12,16$ \\
\hline $\mathrm{C}$ & $23 \pm 1^{\circ} \mathrm{C}$ & $\begin{array}{c}\text { present } \\
- \text { without contact } \\
\text { with the impression }\end{array}$ & 10 & $1,34,9,29,30,10,36,32,8,24$ \\
\hline $\mathrm{D}$ & $23 \pm 1^{\circ} \mathrm{C}$ & $\begin{array}{c}\text { presence }- \text { wrapped } \\
\text { around the impression }\end{array}$ & 10 & $23,3,4,40,37,5,33,15,39,20$ \\
\hline
\end{tabular}

a way that it did not have direct contact with the impression (temperature $23 \pm 1{ }^{\circ} \mathrm{C}$ ). In the fourth group (D), all impressions were directly covered with a wet paper towel and placed in double-zipped bags (temperature $23 \pm 1^{\circ} \mathrm{C}$ ). The allocation into groups and characteristics of the impression storage environment are described in Table 1.

The process of data collection in the form of scans was repeated for each impression after 24 and 144 hours, thus obtaining 120 three-dimensional images of alginate impressions. All scanning procedures were performed by the same scanner operator with the same imaging protocol assumptions. The images exported in the form of STL files were then imported into GOM Inspect Suite software to compare the changes occurring in impressions against time and storage conditions. Using the initial three-dimensional images as reference models, the 3-D images obtained after 24 and 144 hours were superimposed onto the reference models by selecting the "Initial Alignment" command in the software. Subsequently, by indicating on the scan the area of the teeth and 1/3 of the anterior part of the palate, the command "Main Alignment - Local Best-Fit" was executed, thus obtaining two three-dimensional images with
(A) wyciski alginatowe były przechowywane w temperaturze pokojowej $\left(23 \pm 1^{\circ} \mathrm{C}\right)$. Grupe drugą (B) stanowiły wyciski alginatowe umieszczone w warunkach chłodniczych $\left(5 \pm 1^{\circ} \mathrm{C}\right)$. W grupie trzeciej (C) mokry ręcznik papierowy był umieszczany wewnątrz toreb z podwójnym zapięciem strunowym w taki sposób, aby nie kontaktował się $\mathrm{z}$ wyciskiem $\mathrm{z}$ masy alginatowej (temp. $23 \pm 1^{\circ} \mathrm{C}$ ). W grupie czwartej (D) wszystkie wyciski były pokrywane mokrym papierowym ręcznikiem, następnie umieszczane w torbach z podwójnym zapięciem strunowym (temp. $23 \pm 1^{\circ} \mathrm{C}$ ). Podział na grupy wraz z charakterystyką środowiska przechowywania wycisków został opisany w tabeli 1 .

Kompletowanie danych w postaci skanów było ponawiane dla każdego wycisku po 24 oraz po 144 godzinach uzyskując w ten sposób 120 trójwymiarowych obrazów wycisków alginatowych. Wszystkie procedury skanowania były przeprowadzone przez tego samego operatora skanera z tymi samymi założeniami obrazowania. Wyeksportowane obrazy w postaci plików STL były następnie importowane do oprogramowania GOM Inspect Suite w celu porównania zmian zachodzących w wyciskach względem czasu i warunków przechowywania. Wykorzystując trójwymiarowe 
graphically illustrated discrepancies between the reference and the superimposed image (Fig. 1). In order to obtain discrepancy images in the form of numerical values, the scan's surface deviations were measured in five reference points for each tooth imaged on the impression from 17 to 27 , acquiring discrepancy values in millimeters (Fig. 2). The deviation numerical values were exported to Microsoft Excel separately for each group with the division of time ( 24 or 144 hours), and subsequently changed from millimeters to absolute micrometer values. The obtained data were statistically analyzed using the Kruskal-Wallis test and Dunn's post-hoc tests to compare the groups. The level of significance was set at $\alpha=0.05$. The analysis was performed using the Statistica 13 program (TIBCO Software Inc.).

\section{Results}

From 40 standardized alginate impressions, 120 three-dimensional images were obtained in the form of scans (Fig. 1). In the procedure of the discrepancy measurement, by superimposing the examined scans on the reference images (Fig. 2), the deviation maps were obtained with 70 values for each pair of compared three-dimensional images (Fig. 3) (5 points for the imaged teeth from 17 to 27 (Fig. 4), thus obtaining a total number of 5600 values, 1400 for each group).

The results of the performed statistical analysis demonstrate the highest mean deviation from the reference levels after 24 hours in group D, reaching the value of $75.63 \mu \mathrm{m}$. The highest mean discrepancy in the 144th hour of the study was observed for group B impressions with the value of $104.41 \mu \mathrm{m}$. The lowest mean values after 24 hours were achieved in group A $(44.29 \mu \mathrm{m})$, after 144 hours in group $\mathrm{C}(60.13 \mu \mathrm{m})$. The mean values of discrepancies are presented in Table 2. The mean value of deviation from obrazy wstępne jako modele referencyjne, nakładano na nie trójwymiarowe obrazy uzyskane po 24 oraz 144 godzinach wybierając w oprogramowaniu komendę „Bazowania wstępnego". Następnie zaznaczając na skanie okolicę zębów i 1/3 przednią część podniebienia wybierano komendę „Bazowania głównego - lokalny best-fit" otrzymując w ten sposób nałożone na siebie dwa trójwymiarowe obrazy ze zobrazowanymi odchyleniami pomiędzy obrazem referencyjnym a obrazem nakładanym (ryc. 1). W celu uzyskania obrazów odchyleń w postaci wartości liczbowych dokonano pomiaru dyskrepancji powierzchni skanów w 5 miejscach dla każdego zobrazowanego na wycisku zęba od 17 do 27, uzyskując wartości odchyleń w milimetrach (ryc. 2). Dane liczbowe odchyleń zostały wyeksportowane do programu Microsoft Excel oddzielnie dla każdej grupy oraz z podziałem na czas (24 lub 144 godziny), a następnie przemianowane $\mathrm{z}$ wartości milimetrowych na bezwzględne wartości mikrometrowe. Przeprowadzono analizę statystyczną uzyskanych danych, stosując test Kruskala-Wallisa oraz testy post-hoc Dunna w celu porównania poszczególnych grup. Przyjęto poziom istotności $\alpha=0,05$. Analizy dokonano przy pomocy programu Statistica 13 (TIBCO Software Inc.).

\section{Wyniki}

Z 40 ustandaryzowanych wycisków alginatowych uzyskano 120 trójwymiarowych obrazów w postaci skanów (ryc. 1). W procedurze pomiaru dyskrepancji poprzez nakładanie na skany referencyjne skanów badanych (ryc. 2) otrzymano mapy odchyleń z których wyodrębniono po 70 wartości dla każdej porównywanej pary trójwymiarowych obrazów (ryc. 3) (po 5 punktów dla zobrazowanych zębów od 17 do 27 (ryc. 4), uzyskując w ten sposób łączną liczbę 5600 wartości po 1400 dla każdej z grup. 


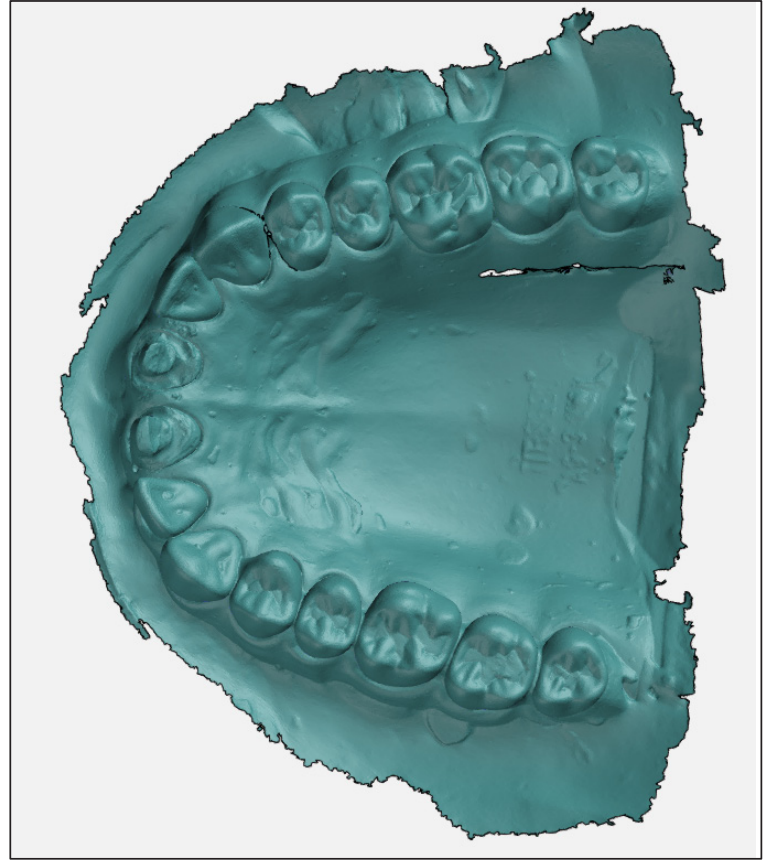

Fig. 1. The image of the alginate impression's scan imported into the GOM Inspect software.

Ryc. 1. Obraz skanu wycisku alginatowego po zaimportowaniu do programu GOM Inspect.

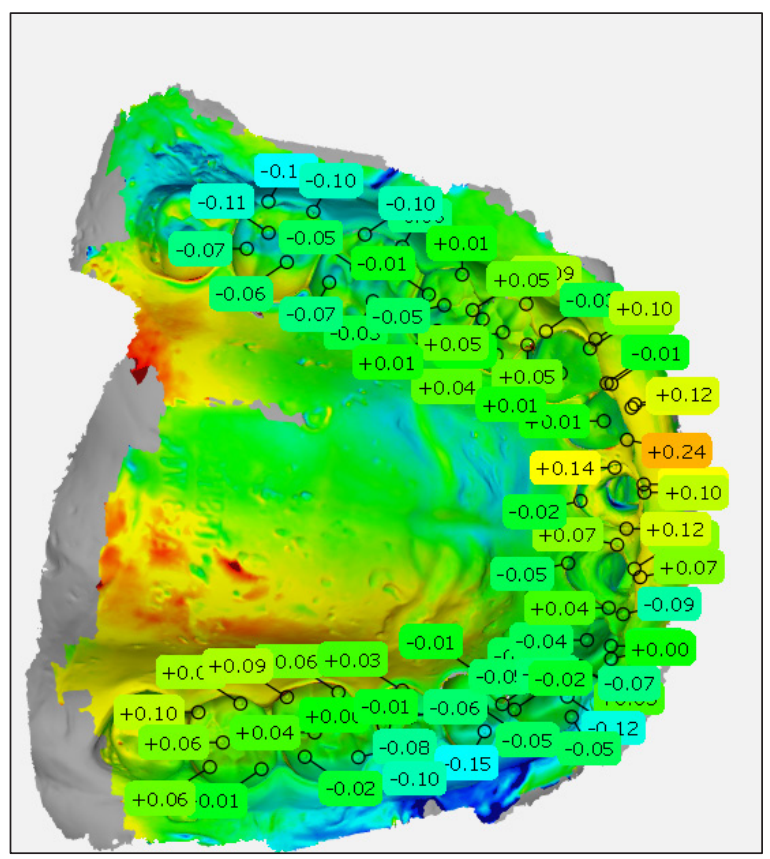

Fig. 3. 70 deviation points selected for the pair of compared scans.

Ryc. 3. Zaznaczone 70 punktów odchyleń dla pary porównywanych skanów.

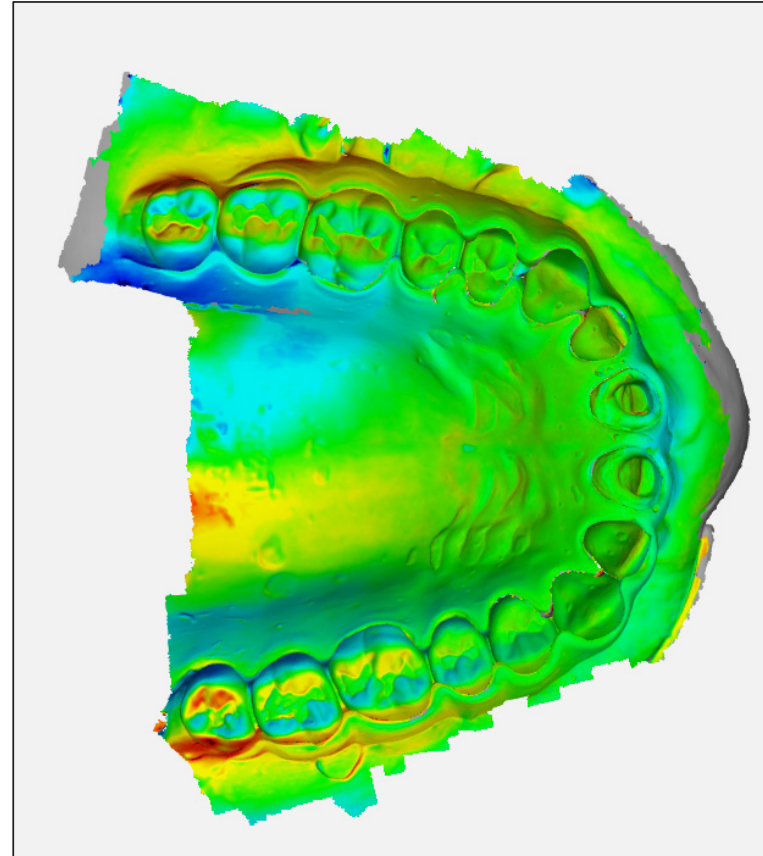

Fig. 2. Colour indication of the discrepancy between the reference and the examined scan.

Ryc. 2. Kolorystyczne oznaczenie dyskrepancji pomiędzy skanem referencyjnym a badanym.

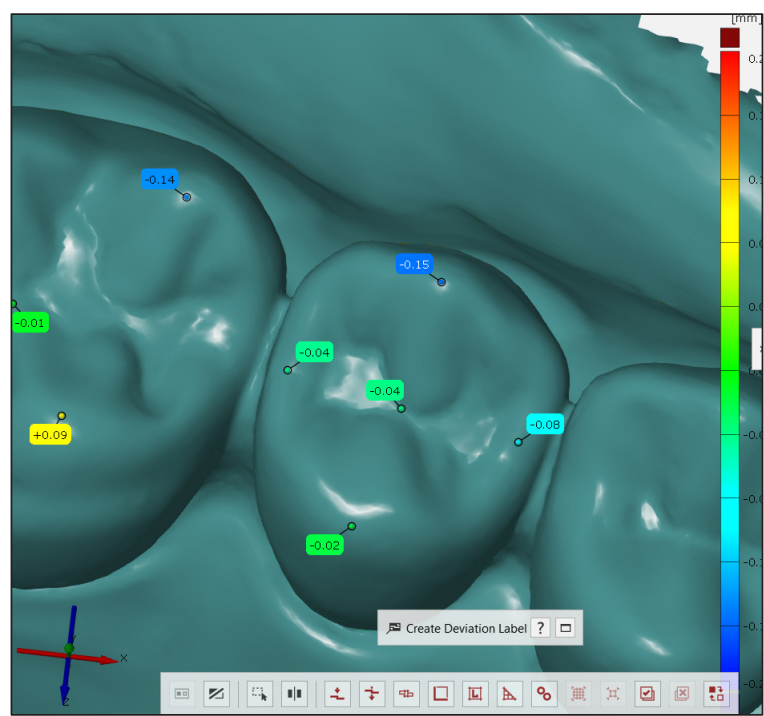

Fig. 4. Discrepancy values at five points of the imaged tooth.

Ryc. 4. Wartości odchyleń w pięciu punktach zobrazowanego zęba. 
Ta b le 2. Average deviations in individual groups in the form of numerical data and the graph

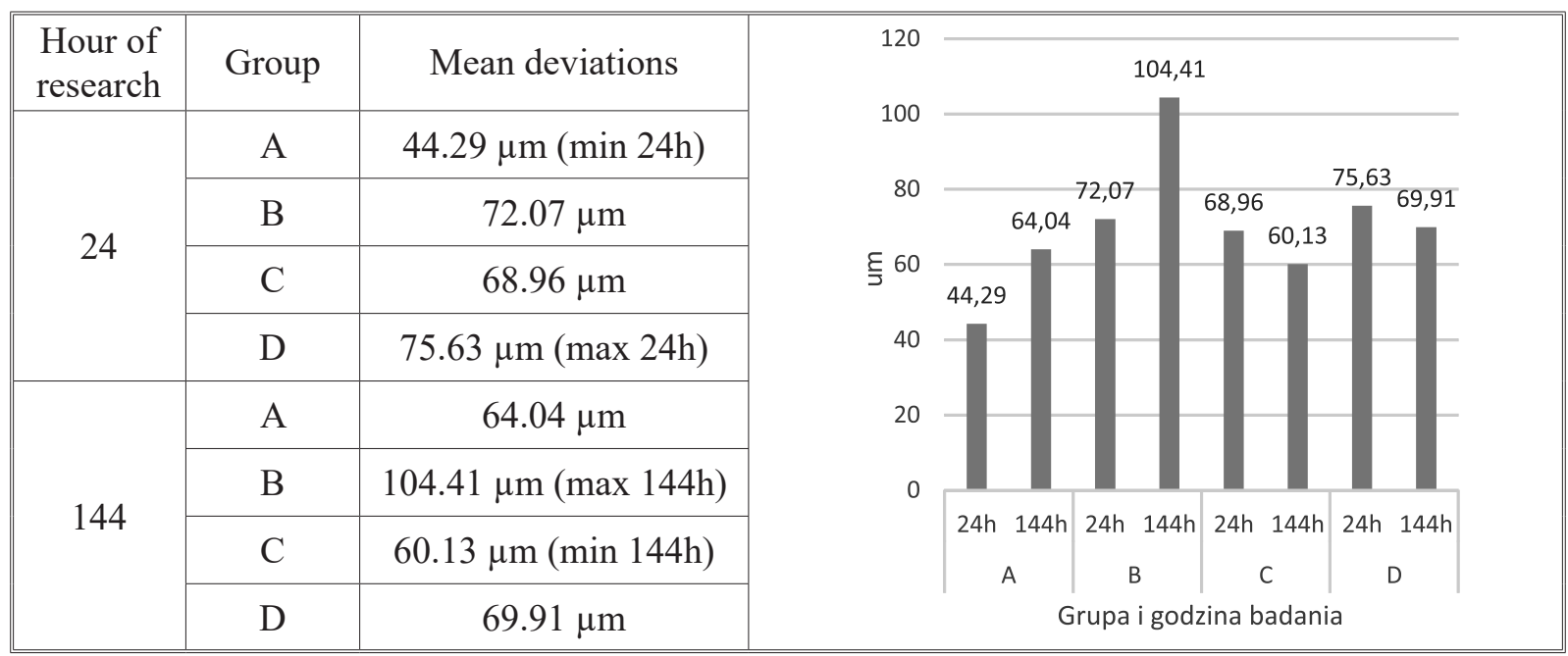

Ta b le 3. The results of Dunn's post-hoc test with the division into groups and hours of the study (values marked in red present statistically significant differences)

\begin{tabular}{|c|c|c|c|c|c|c|c|c|}
\hline \multicolumn{2}{|c|}{} & A & \multicolumn{2}{c|}{ B } & \multicolumn{2}{c|}{ C } & \multicolumn{2}{c|}{ D } \\
\cline { 3 - 10 } & $144 \mathrm{~h}$ & $24 \mathrm{~h}$ & $144 \mathrm{~h}$ & $24 \mathrm{~h}$ & $144 \mathrm{~h}$ & $24 \mathrm{~h}$ & $144 \mathrm{~h}$ \\
\hline \multirow{3}{*}{$\mathrm{A}$} & $24 \mathrm{~h}$ & $\mathbf{0 . 0 0 0 0 0 0}$ & $\mathbf{0 . 0 0 0 0 0 0}$ & $\mathbf{0 . 0 0 0 0 0 0}$ & $\mathbf{0 . 0 0 0 0 0 0}$ & $\mathbf{0 . 0 0 0 0 1 7}$ & $\mathbf{0 . 0 0 0 0 0 0}$ & $\mathbf{0 . 0 0 0 0 0 0}$ \\
\cline { 2 - 10 } & $144 \mathrm{~h}$ & - & 1.000000 & $\mathbf{0 . 0 0 0 0 0 0}$ & 1.000000 & 1.000000 & 0.067700 & 1.000000 \\
\hline \multirow{2}{*}{$\mathrm{B}$} & $24 \mathrm{~h}$ & - & - & $\mathbf{0 . 0 0 0 0 0 0}$ & 1.000000 & 0.065636 & 1.000000 & 1.000000 \\
\cline { 2 - 10 } & $144 \mathrm{~h}$ & - & - & - & $\mathbf{0 . 0 0 0 0 0 0}$ & $\mathbf{0 . 0 0 0 0 0 0}$ & $\mathbf{0 . 0 0 0 0 0 0}$ & $\mathbf{0 . 0 0 0 0 0 0}$ \\
\hline \multirow{2}{*}{$\mathrm{C}$} & $24 \mathrm{~h}$ & - & - & - & - & $\mathbf{0 . 0 3 9 5 2 4}$ & 1.000000 & 1.000000 \\
\cline { 2 - 10 } & $144 \mathrm{~h}$ & - & - & - & - & - & $\mathbf{0 . 0 0 0 0 5 5}$ & 0.599000 \\
\hline $\mathrm{D}$ & $24 \mathrm{~h}$ & - & - & - & - & - & - & 0.392859 \\
\hline
\end{tabular}

all the performed measurements, independent of the storage conditions, was $69.93 \mu \mathrm{m}$. The Kruskal-Wallis test for independent groups demonstrated statistically significant differences between the groups ( $p$-value $<0.000$ ). The performed post-hoc Dunn tests showed statistically significant differences between individual groups, and the results of the analysis are presented in Table 3 the results indicating statistically significant differences are marked in red.
Wyniki przeprowadzonej analizy statystycznej dowodzą największego średniego odchylenia od poziomów referencyjnych po 24 godzinach w grupie D osiągając wartość 75,63 $\mu \mathrm{m}$. Największa średnia dyskrepancja w 144 godzinie badania została zaobserwowana dla grupy B i wynosiła 104,41 $\mu \mathrm{m}$. Najmniejsze wartości średnie po 24 godzinach osiągnęła grupa A $(44,29 \mu \mathrm{m})$, po 144 godzinach badania grupa C $(60,13 \mu \mathrm{m})$. Wartości średnich dyskrepancji obrazuje tabela 2. Niezależna od 


\section{Discussion}

Despite the dynamic development of digital intraoral scanning techniques and the expansion of advanced silicone impression materials, hydrocolloid alginate ones remain the most frequently chosen material for imprinting the patient's intra-oral conditions. In treatment procedures, they are used to make working casts, e.g. for removable prosthetic restorations, as well as for diagnostic or preliminary models in various dental specialties. The hydrophilic nature of irreversible hydrocolloids is their advantage while making impressions in the wet environment of the oral cavity. At the same time, alginates undergo the process of expansion due to water absorption, as well as contraction as a result of water removal from the bound material. In the study conducted by Garg et al. it was found that the presence of calcium ions (when casting the models) induces shrinkage upon contact with the bound alginate materials, and it is believed to be a result of additional cross-linkages being formed in the gel. The water in the alginate gel may be free or bound. Free water is being trapped between the filler particles, and is prone to increase or decrease its volume as a result of evaporation or absorption. The appropriate ratio of alginate powder to water and the use of distilled water, as was the case in the present study, can therefore be crucial for the volumetric stability regardless of the material used: traditional or with the high dimensional stability. However, Fellows et al. proved that dimensional stability of alginates increased with a higher ratio of the filler, i.e. diatomaceous earth, to alginate polymer. Imbery et al. argued that there was a relationship between the molecular weight of alginate and its delayed stability after setting, and stated that materials described as "extendedpour alginates" were more accurate than the initial situation in a function of time. The research carried out in the present study shows warunków przechowywania średnia wartość odchylenia ze wszystkich wykonanych pomiarów wyniosła 69,93 $\mu \mathrm{m}$. Przeprowadzony test Kruskala-Wallisa dla grup niezależnych wykazał istotne statystycznie różnice pomiędzy grupami (wartość $\mathrm{p}<0,000$ ). Wykonane testy post-hoc Dunna zobrazowały różnice istotne statystycznie pomiędzy poszczególnymi grupami, a wyniki analizy reprezentuje tabela 3 - wytłuszczeniem oznaczono wyniki obrazujące różnice istotne statystycznie.

\section{Dyskusja}

Mimo dynamicznego rozwoju cyfrowych technik skanowania wewnątrzustnego oraz rozpowszechnienia specjalistycznych wyciskowych materiałów silikonowych, hydrokoloidowe masy alginatowe w dalszym ciągu stanowią najczęściej wykorzystywaną metodę odwzorowania warunków wewnątrzustnych pacjenta, służąc do wykonania modeli roboczych $\mathrm{w}$ procedurach leczenia np. ruchomymi uzupełnieniami protetycznymi oraz diagnostycznych i pomocniczych w wielu specjalnościach stomatologicznych. Hydrofilny charakter nieodwracalnych hydrokoloidów jest ich zaletą podczas wykonywania wycisków w wilgotnym środowisku jamy ustnej. Jednocześnie alginiany podlegają procesowi ekspansji na skutek wchłaniania wody, oraz kurczenia w wyniku odprowadzenia wody ze związanej masy. W badaniach Garg i wsp. stwierdzono, że obecność jonów wapnia (podczas odlewania modeli gipsowych) kontaktując ze związaną masą alginatową indukuje skurcz i uważa się, że jest to spowodowane tworzeniem dodatkowych połączeń sieciujących w żelu. Woda w żelu alginianowym może być wolna lub związana. Wolna woda jest uwięziona między cząstkami wypełniacza i jest podatna na zwiększanie się lub zmniejszanie w wyniku parowania lub wchłaniania. Odpowiedni stosunek proszku alginatowego do wody oraz wykorzystanie wody 
that such a situation takes place regardless of supplying an external source to provide an increase in humidity to the impression storage environment - the minimum average value of the deviation from the reference scan at 144 hours of the study occurred in the group with a wet towel placed in a double-zipped bag without contact with the impression; however, the difference between this group and the group in which the impression had been placed in the double-zipped bag without any additional sources to potentially increase the humidity was statistically insignificant. ${ }^{15-17}$ Guiraldo et al. examined the existence of variations in the inorganic composition of the filler particles. Among five alginate materials that were selected for the study, Hydrogum 5 showed the highest content of inorganic filler $(84.85 \%)$, therefore for this particular material, the lowest volumetric change is expected to occur. In their study, Sedda et al. confirmed the generally prevailing opinion that the greatest accuracy could be obtained when plaster models were cast immediately on the basis of alginate impressions. However, the researchers investigated mainly the traditional alginate materials, which in the face of the present and cited studies seems to remain a decisive factor for such results. ${ }^{18,19}$ In the authors' opinion, the validity of taking into consideration conclusions drawn from the studies investigating the impact of environmental factors with a generalization of all impression materials described as alginates, without separating those with "increased stability", may presumably turn out to be inadequate, because the percentage and proportions of specific components can contribute to changes in materials, and those can vary across individual products, even from the same manufacturer.

Taking into consideration the model of cooperation between dental offices and laboratories, the first measurement of the spatial dimensions variability of alginate impressions destylowanej, tak jak to miało miejsce w niniejszym badaniu, może być więc kluczowe dla stabilności objętościowej niezależnie od zastosowanej masy: tradycyjnej lub o wysokiej stabilności wymiarowej. Fellows i wsp. dowiedli natomiast, iż stabilność wymiarowa alginianów wzrasta przy wyższym stosunku wypełniacza, czyli ziemi okrzemkowej, do polimeru alginianowego. Imbery i wsp. przekonują, iż istnieje związek między masą cząsteczkową alginianu, a jego odroczoną stabilnością po związaniu jednocześnie zaznaczając, iż masy opisywane jako „extended-pour alginates” cechują się większą dokładnością w stosunku do sytuacji wyjściowej w funkcji czasu. Z badań własnych przeprowadzonych w obecnej pracy wynika, iż ma to miejsce niezależnie od tego czy do środowiska przechowywania wycisku alginatowego zostanie dostarczone zewnętrzne źródło zwiększające wilgotność - minimalna średnia wartość odchylenia od skanu referencyjnego w 144 godzinie badania wystąpiła w grupie z mokrym ręcznikiem umieszczonym w torebce strunowej bez kontaktu z wyciskiem, jednak różnica pomiędzy tą grupą, a grupą w której wycisk był umieszczany w torebce strunowej bez żadnych dodatkowych źródeł zwiększających potencjalnie wilgotność była nieistotna statystycznie. ${ }^{13-15}$ Guiraldo i wsp. zbadali występowanie różnic $\mathrm{w}$ nieorganicznym składzie cząstek wypełniacza. Spośród wybranych do badania pięciu mas alginatowych, Hydrogum 5 wykazał się największą zawartością nieorganicznego wypełniacza (84.85\%), przez co w przypadku tej masy oczekuje się najmniejszej zmiany objętościowej. Sedda i wsp. potwierdzili ogólnie panującą opinię, iż największą dokładność można otrzymać, gdy modele gipsowe są odlewane na podstawie wycisków alginatowych jak najszybciej. Badali oni jednak głównie tradycyjne masy alginatowe, co w obliczu własnych i przytoczonych badań wydaje się czynnikiem decydującym o takich wynikach. ${ }^{16,17} \mathrm{~W}$ ocenie własnej autorów niniejszej 
was made after one day, assuming that in the vast majority of cases it might be the approximate time required to transport the impression from the dental office to the laboratory. It was observed that after 24 hours the lowest mean change in volume $(44.29 \mu \mathrm{m})$ occurred in the group stored without the increase of humidity of the environment. The highest mean discrepancy between reference images and scans which were taken after 24 hours occurred in the group where impressions were stored at room temperature and covered with a wet paper towel, which could indicate prolonged water absorption by the alginate material. With time, the mean values of deviations from the reference scans varied in all the groups. It must be noted that the minimal change between 24 and 144 hours of the study was observed in the group where the impressions were stored at room temperature and covered with a wet paper towel - here the difference in the mean deviation was the lowest of the entire study $(5.72 \mu \mathrm{m})$. Therefore, it can be concluded that the processes of imbibition and syneresis are significantly intensified at the initial stage and are subsequently balanced or occur to a very minimal extend. At the same time, the change that was observed during the first 24 hours was so high in this group that the mean deformation was higher than in the group without additional sources of increased humidity.

The accurate and undisturbed by external factors process of imaging the prosthetic field has a direct impact on the optimal manufacturing of the future prosthetic restoration, becoming one of the most critical aspects of the clinical success and the minimization of complications during and after treatment. The authors of the present study did not manage to find standards defining the maximum acceptable deviations for alginate materials. Quante et al. reported the value of 74 and 99 microns as an acceptable value for the marginal accuracy of metal-based ceramic crowns. Syrek et al. in their study on the pracy, zasadność przekładania wniosków płynących z badań na temat wpływu czynników środowiskowych uogólniając wszystkie masy wyciskowe określane jako alginatowe bez wydzielenia tych o „zwiększonej stabilności”, przypuszczalnie może okazać się niepełnowartościowe, ponieważ zawartość procentowa i proporcje określonych składników mogą determinować zachodzące w nich zmiany, a te różnią się w obrębie poszczególnych produktów nawet $u$ tego samego producenta.

Biorąc pod uwagę model współpracy gabinetów stomatologicznych z pracowniami techniki dentystycznej, pierwszy pomiar zmienności wymiarów przestrzennych wycisków alginatowych wykonano po jednej dobie, zakładając, iż może to być w znacznej większości przypadków orientacyjny czas potrzebny na transport wycisku z gabinetu do laboratorium. Wykazano, że po 24 godzinach najmniejsza średnia zmiana objętości $(44,29 \mu \mathrm{m})$ wystąpiła w grupie przechowywanej bez zwiększania wilgotności otoczenia. Największa średnia dyskrepancja pomiędzy skanami referencyjnymi a pobranymi po 24 godzinach wystąpiła w przypadku wycisków przechowywanych $\mathrm{w}$ temperaturze pokojowej $\mathrm{z}$ owinięciem ich mokrym papierowym ręcznikiem co może świadczyć o przedłużonym chłonięciu wody przez masę alginatową. Wraz z upływem czasu średnie wartości odchyleń od skanów referencyjnych zmieniały się we wszystkich grupach. Uwagę zwraca minimalna zmiana na przestrzeni pomiędzy 24 a 144 godziną badania w grupie wycisków przechowywanych w temperaturze pokojowej z dostarczania źródła wilgoci w torbie strunowej owiniętego dookoła wycisku alginatowego - różnica średniego odchylenia była tutaj najmniejsza $\mathrm{z}$ całego badania $(5,72 \mu \mathrm{m})$, a więc można wnioskować, iż procesy imbibicji i synerezy po wstępnym znacznym nasileniu występowały w najmniejszym stopniu lub równoważyły się. Jednocześnie, zmiana zachodząca w tej grupie w ciągu pierwszych 24 godzin 
accuracy of all-ceramic crowns produced on the basis of intra-oral scans, give the value of 49 microns as being within clinically acceptable limits. While investigating polyvinylsiloxane materials, Stober et al. defined the limit value of the accuracy of clinical situation mapping at $150-100 \mu \mathrm{m}$. The mean range of deviations obtained in the present study is $69.93 \mu \mathrm{m}$, fitting in most of the quoted acceptable ranges, indicating the high stability of the Hydrogum 5 material. Similar conclusions are drawn from the study conducted by Sahin et al., who stated that each of the alginate materials (with high dimensional stability) used in their research, including the material which is the subject of the present publication, remained compliant with the accepted standards after 120 hours of storage. However, despite this fact, in the authors' opinion Hydrogum 5 as an alginate material due to other limitations (e.g. consistency), was not recommended as an impression material for high-precision works, such as prosthetic crowns. ${ }^{20-23}$

The authors of the present study did not find in the literature any standard assumptions for researching the dimensional stability of impressions taken with alginate materials. In the available publications, most authors use various shapes of forms to take an impression, usually they are simple geometric figures or phantom exercise models. The most frequent protocol for controlling the accuracy of mapping or dimensional stability of alginate impressions is the use of digital calipers or computer software-to determine the distance between arbitrarily indicated points on the images (usually they are points located on the lateral teeth on the opposite sides). ${ }^{14,24,25}$ In the present study, two three-dimensional images of the scanned impressions were entirely compared to each other, and only the number of deviation points was chosen arbitrarily by the authors. The limitation of the study could include the selection of points (five points on była na tyle duża, iż średnie odkształcenie w tej grupie było wyższe niż w grupie bez dodatkowych źródeł wilgotności.

Dokładne, niezaburzone czynnikami zewnętrznymi odwzorowanie pola protetycznego ma bezpośredni wpływ na optymalne wykonanie przyszłej pracy protetycznej, stając się jedną z najważniejszych składowych sukcesu klinicznego oraz minimalizacji komplikacji w przebiegu i po leczeniu. Autorom obecnej pracy nie udało się odnaleźć norm opisujących maksymalne dopuszczalne odchylenia dla mas alginatowych. Quante i wsp. podają wartość 74 i 99 mikronów jako wartość akceptowalną przy szczelności brzeżnej koron ceramicznych na podbudowie metalowej. Syrek i wsp. w pracy opisującej dokładność wykonywania koron pełnoceramicznych na podstawie skanów wewnątrzustnych podają wartość 49 mikronów jako mieszczącą się w granicach dopuszczalnych klinicznie. Stober i wsp. opisując masy poliwinylosiloksanowe określają wartość graniczną dokładności odwzorowania sytuacji klinicznej na 150-100 $\mu \mathrm{m}$. Średni zakres odchyleń uzyskany w niniejszym badaniu własnym wynosi 69,93 $\mu \mathrm{m}$ mieszcząc się zatem w większości przytoczonych dopuszczalnych zakresów, co wskazuje na wysoką stabilność masy Hydrogum 5. Analogiczne wnioski płyną z badania Sahin i wsp. dowodząc, że każda $\mathrm{z}$ użytych w ich badaniu masa alginatowa (o wysokiej stabilności wymiarowej), w tym masa będąca przedmiotem obecnej publikacji, po 120 godzinach przechowywania pozostawała zgodna ze standardami. Jednak w ocenie autorów obecnej pracy, nie zmienia to faktu, iż Hydrogum 5 jako masa alginatowa, ze względu na inne ograniczenia (np. konsystencję) nie jest zalecana do wykonywania wycisków w celu wykonania wysoko precyzyjnych prac, takich jak np. korony protetyczne. ${ }^{18-21}$

Autorzy obecnej pracy nie znaleźli w piśmiennictwie standardowych założeń przeprowadzania badań dotyczących stabilności 
each tooth) for the measurement of discrepancy on heat maps, which as a result of the GOM Inspect program's possibilities, were applied manually according to the previously adopted criteria. However, as for the obtained results, it can be concluded that minor variations between the indicated points due to a large number of individual results (5600 measurement points) are acceptable without interfering with the overall test result.

\section{Conclusions}

1. The storage time and environment affect the spatial dimensions of alginate impressions, and the tested alginate materials (with high dimensional stability) were characterized by a relatively low degree of volumetric change both after 24 and 144 hours.

2 . The best way to store the impression depends on the estimated time when the process of model casting is to be started.

3 . The presence of an external source that increases the humidity of the storage environment of alginate impression does not significantly improve their spatial stability in the case of a material with high dimensional stability. wymiarów wycisków pobieranych masami alginatowymi. W dostępnych publikacjach większość autorów wykorzystuje różnokształtne formy wyciskowe, zazwyczaj będące prostymi figurami geometrycznymi lub fantomowymi modelami ćwiczeniowymi. Najczęściej występującym protokołem kontroli dokładności odwzorowania lub stabilności wymiarów wycisków alginatowych jest wykorzystanie cyfrowych suwmiarek lub komputerowych systemów wyznaczania odległości na obrazach pomiędzy przyjętymi arbitralnie punktami (na ogół są to punkty wyznaczone na zębach bocznych po przeciwnych stronach). ${ }^{12,22,23} \mathrm{~W}$ niniejszym badaniu własnym dwa trójwymiarowe obrazy zeskanowanych wycisków były w całości do siebie porównywane, a jedynie ilość punktów odchyleń została przyjęta arbitralnie przez autorów. Ograniczenie badania mógł stanowił dobór punktów (po 5 punktów na każdym zębie) do pomiaru dyskrepancji na mapach odchyleń (ang. heat maps), które ze względu na możliwości programu GOM Inspect nanoszone były ręcznie według wcześniej przyjętych kryteriów, jednak w przypadku uzyskanych wyników można wnioskować, że niewielkie różnice pomiędzy wyznaczonymi punktami ze względu na znaczną ilość jednostkowych wyników (5600 punktów pomiarowych) są dopuszczalne nie ingerując $\mathrm{w}$ całościowy wynik badania.

\section{Wnioski}

1. Czas oraz środowisko przechowywania mają wpływ na zmianę wymiarów przestrzennych wycisków alginatowych, a badana masa alginatowa (o wysokiej stabilności wymiarowej) charakteryzuje się stosunkowo niskim stopniem zmiany objętościowej zarówno po 24 jak i po 144 godzinach.

2. Najlepszy sposób przechowywania wycisku jest uzależniony od zakładanego czasu 
do momentu rozpoczęcia odlewania modelu gipsowego.

3. Obecność zewnętrznego źródła zwiększającego wilgotność środowiska przechowywania wycisków alginatowych nie wpływa znacząco na polepszenie ich stabilności wymiarów przestrzennych w przypadku masy o wysokiej stabilności wymiarowej.

\section{References / Piśmiennictwo}

1. Petropoulos VC, Rashedi B: Current concepts and techniques in complete denture final impression procedures. J Prosthodont 2003; 12: 280-287. doi:10.1016/s1059-941x(03)00108-6.

2. Cervino G, Fiorillo L, Herford AS, Laino L, Troiano G, Amoroso G, Crimi S, Matarese $M$, et al.: Alginate Materials and Dental Impression Technique: A Current State of the Art and Application to Dental Practice. Mar Drugs 2018; 17(1): 18. doi:10.3390/ md17010018.

3. Carlo HL, Fonseca RB, de Souza Goncalves L, Correr-Sobrinho L, Soares CJ, Sinhoreti $M A C$ : Analysis of filler particle levels and sizes in dental alginates, Materials Res. 2010; 13(2): 261-264.

4. Szerszeń M, Surowiecki D, Tyrajski M: Wpływ warunków przechowywania wycisków wykonanych masą alginatową na ich wymiary przestrzenne. Protet Stomatol 2018; 68(4): 406414. doi: 10.5114/ps/100516.

5. Hamedi Rad F, Ghaffari T, Safavi SH: In vitro evaluation of dimensional stability of alginate impressions after disinfection by spray and immersion methods. J Dent Res Dent Clin Dent Prospects 2010; 4(4): 130-135. doi: 10.5681/joddd.2010.032

6. Hulme $C, Y u$, Browne C, O'Dwyer J, Craddock H, Brown S, Gray J, Pavitt S, Fernandez C, Godfrey $M$, Dukanovic $G$, Brunton P, Hyde TP: Cost-effectiveness of silicone and alginate impressions for complete dentures. J Dent 2014; 42(8): 902-907. doi: 10.1016/j.jdent.2014.03.001

7. Buchan S, Peggie RW: Role of ingredients in alginate impression compounds. J Dent Res 1966; 45: 1120-1129.

8. Morrow RM, Rudd KD, Eissmann HF: Preliminary impressions: Care and pouring. In: Dental Laboratory Procedures: Complete dentures, 1st ed. St. Louis: Mosby, 1980.

9. Dahl LB, Dymbe B, Valderhaug J: Bonding properties and dimensional stability of hydrocolloid impression systems in fixed prosthodontics. J Prosthet Dent 1985; 53: 796-800.

10. Farzin M, Panahandeh $H$ : Effect of pouring time and storage temperature on dimensional stability of casts made from irreversible hydrocolloid. J Dent (Tehran) 2010; 7(4): 179184.

11. Abdelraouf RM: Chemical analysis and microstructure examination of extended-pour alginate impression versus conventional one (characterization of dental extended-pour alginate). International Journal of Polymeric Materials and Polymeric Biomaterials 2017; 67(10): 612-618. doi: 10.1080/00914037.2017.1362636.

12. Todd JA, Oesterle LJ, Newman SM, Shellhart $W C$ : Dimensional changes of extended-pour alginate impression materials. Am J Orthod Dentofacial Orthop 2013; 143(4Suppl): S55-S63. doi: 10.1016/j.ajodo.2012.06.016.

13. Garg S, Mittal S, Bansal S, Kansal G: A Study on Imbibition and Syneresis in Four Commercially Available Irreversible Hydrocolloid (Alginate) Impression Materials. Inter J Prosth Res Dent 2012; 2: 1-4. doi: 10.5005/jp-journals-10019-1037.

14. Imbery TA, Nehring J, Janus C, Moon PC: 
Accuracy and dimensional stability of extended-pour and conventional alginate impression materials. J Am Dent Assoc 2010; 141(1): 32-39. doi: 10.14219/jada.archive.2010.0018.

15. Fellows CM, Thomas GA: Determination of bound and unbound water in dental alginate irreversible hydrocolloid by nuclear magnetic resonance spectroscopy. Dent Mater 2009; 25 : 486-93. doi: 10.1016/j.dental.2008.10.001.

16. Guiraldo RD, Berger SB, Consani RL, Consani $S$, de Carvalho $R V$, Lopes $M B$, Meneghel LL, da Silva FB, Sinhoreti MA: Characterization of morphology and composition of inorganic fillers in dental alginates. Biomed Res Int 2014; 2014: 178064. doi: 10.1155/2014/178064.

17. Sedda M, Casarotto A, Raustia A, Borracchini $A$ : Effect of storage time on the accuracy of casts made from different irreversible hydrocolloids. J Contemp Dent Pract 2008; 9(4): 59-66.

18. Quante K, Ludwig K, Kern M: Marginal and internal fit of metal-ceramic crowns fabricated with a new laser melting technology. Dent Mater 2008; 24(10): 1311-1315. doi: 10.1016/j.dental.2008.02.011.

19. Syrek A, Reich G, Ranftl D, Klein C, Cerny B, Brodesser J: Clinical evaluation of all-ceramic crowns fabricated from intraoral digital impressions based on the principle of active wavefront sampling. J Dent 2010; 38(7): 553559. doi: 10.1016/j.jdent.2010.03.015.

20. Stober T, Johnson GH, Schmitter M: Accuracy of the newly formulated vinyl siloxanether elastomeric impression material. J Prosthet Dent 2010; 103(4): 228-239. doi: 10.1016/ S0022-3913(10)60035-2.

21. Sahin V, Jodati H, Evis Z: Effect of storage time on mechanical properties of extended-pour irreversible hydrocolloid impression materials. J Prosthet Dent 2020; 124(1): 6974. doi: 10.1016/j.prosdent.2019.09.001.

22. Cesur MG, Omurlu IK, Ozer T: Evaluation of digital model accuracy and time-dependent deformation of alginate impressions. Niger J Clin Pract 2017; 20(9): 1175-1181. doi: 10.4103/1119-3077.197012.

23. Rohanian A, Ommati Shabestari G, Zeighami $S$, Samadi MJ, Shamshiri AR: Effect of storage time of extended-pour and conventional alginate impressions on dimensional accuracy of casts. J Dent (Tehran) 2014; 11(6): 655664.

Zaakceptowano do druku: 8.04.2021 r.

Adres autorów: 02-097 Warszawa, ul. Binieckiego 6.

C) Zarząd Główny PTS 2001. 